\title{
Perception of local communities on the sociocultural impacts of rural tourism. Case of Bellavista, El Oro, Ecuador
}

\section{Percepción de las comunidades locales sobre los impactos socioculturales derivados del turismo rural. Caso Bellavista, El Oro, Ecuador}

Lilia Ortíz Berrezueta ${ }^{1}$, Mauricio Noblecilla Grunauer. ${ }^{2}$, Jonathan Ruíz Carrillo ${ }^{3}$, Oscar Ordoñez Contreras ${ }^{4}$ \& Marjorie Crespo García 5 .

\begin{abstract}
This article presents a study on the community perception of tourism and its sociocultural impact from the point of view of the inhabitants of the coastal communes of the Bellavista Parish and areas bordering the La Tembladera wetland, a protected area with a tourist high potential. The references analyzed discuss the sociocultural impact involved in tourist development, interaction and influences between rural communities and tourism. The records obtained were highly reliable according to the reliability analysis (Cronbach's $\mathbf{a}=0.992$ ). Within the analysis, the component that presented the most interactive relationships had to do with the personal safety of the residents, who said that this is not affected by the flow of visitors during the local tourist seasons. The analysis of the sociocultural impact of tourism shows us that this can be related to the perception that the residents of rural communities of Bellavista Parish have.
\end{abstract}

Keywords: Community perception, tourism, sociocultural impact, personal safety, rural communities.
Resumen: En este artículo se presenta una investigación sobre la percepción comunitaria del turismo y su impacto sociocultural desde el punto de vista de los habitantes de las comunas ribereñas de la parroquia Bellavista y sectores aledaños al Humedal La Tembladera, un sector protegido con un alto potencial turístico. Las referencias analizadas discuten el impacto sociocultural que implica el desarrollo turístico, la interacción e influencia entre las comunidades rurales y el turismo. Los registros obtenidos resultaron altamente confiables según el análisis de fiabilidad (Cronbach's $\mathbf{a}=0.992)$. Dentro del análisis el componente que presentó más relaciones de interacción tiene que ver con la seguridad personal de los residentes, la cual manifiestan que no se ve afectada por el flujo de visitantes durante las temporadas turísticas locales. El análisis de los impactos socioculturales del turismo nos muestra que éstos pueden ser relacionados con la percepción que tienen los residentes de las comunidades rurales de la parroquia Bellavista.

Palabras clave: Percepción comunitaria, turismo, impacto sociocultural, seguridad personal, comunidades rurales.

(Presentado: 19 de enero de 2017. Aceptado: 14 de marzo de 2017)

\footnotetext{
${ }^{1}$ Bachelor of Arts in Hotel Management and Tourism, Universidad Técnica de Machala, Ecuador. E-mail: laortizQutmachala.edu.ec

${ }^{2}$ Holder of an Engineering Degree in Business Management, Bank and Finance, Universidad de Especialidades Espíritu Santo.

${ }^{3}$ Máster in Teaching and Educational Research at the Technical University of Machala, jruizQutmachala.edu.ec

${ }^{4}$ Magíster en Planificación y Gestión de Proyectos Agroturísticos y Ecológicos, por la Universidad Agraria del Ecuador, osordonezqutmachala.edu.ec

${ }^{5}$ Magister in Accounting and Auditing, Universidad Metropolitana del Ecuador. E-mail: mcrespoqumet.edu.ec
} 


\section{INTRODUCTION}

According to El Clima (2016), tourism in rural communes was originally developed in Europe as a complementary strategy for socio-economic development in rural populations after the Second World War. That is the reason why in the decades of the seventies and eighties tourism development policies for rural areas were established. In France, rural tourism is carried out based on activities carried out in small farms. In Austria, policies that limit the number of tourist spaces in agrotourism are duly established. In Germany holidays in agricultural farms is a known activity, where urban visitors learn about agricultural activities and the countryside. On the other hand, in Denmark rural tourism is centered in the rent of a full board or half board room, offering activities like fishing, cycling, tennis, horse riding and swimming pool. In the Netherlands, rural tourism is based on agro camping. In Belgium, there are three tourism ways in the countryside: accommodation in a farm that includes lodging, food and agro camping. In Portugal, rural tourism presents four modalities: tourism organized by the farmer, agrotourism, rural tourism, and tourist hunting areas. In Latin America, Chile and Argentina are countries of reference to the widest network of rural tourism associations, where several camping and agrotourism activities are developed.

On the other hand, communes bordering tourist recreation sites, historic landmarks, or any tourist site may think, in some cases, that tourism-related activities may affect their commune in a sociocultural way (Bramwell, 2015; Dolnicar, Yanamandram, \& Cliff, 2012). The effects vary according to the amount of visitors, the activities carried out during their stay as well as their customs or beliefs (Brunt \& Courtney, 1999; Moyle, Croy, \& Weiler, 2010). Bellavista is a highly tourist area, unprepared for tourism though, the reasons to its low tourist affluence is due to a general lack of knowledge of the existence of the site, combined with a lack of publicity or tourist information in the area, another problem could be the little concern to research the potential of tourism resources in the site. Little or no investment in the tourism sector due to the low level of projects based on rural tourism. Deepening the understanding of the situation, there is a location in Bellavista called La Tembladera wetland, where different types of tourism can be developed in benefit of the sociocultural development of the population of the above mentioned place. That is the reason why the problem can be stated based on: how does the low level of perception of rural tourism impacts the sociocultural aspect of the commune of Bellavista?

The argument or purpose pursued hereby is to determine the perception of the residents of these sectors regarding local tourist development in its different stages, or while the tourist affluence is gradually increasing or decreasing. A turning point in the analysis is the high season of tourism, holiday or summer season, as the case may be (Chen, Hsu, \& Tzeng, 2011; Wang, Chen, \& Chen, 2012).

\section{History of Bellavista}

According to GAD Bellavista (2016), the Parish of Bellavista in the Canton of Santa Rosa, El Oro Province, was first colonized around 1870, among the first families of settlers the following can be mentioned: Aguilar, Lozano, Zambrano, Macas, Torres, Zavala and Pesantes. Originally known as Pitapongo, a small river dock named Botadero was established for the trade of products and their transportation to Santa Rosa. Similarly, on April 27, 1907 the Municipality of Santa Rosa promoted to parish the civil estate named "Pitapongo", changing its name to Bellavista due to its wonderful flora and fauna, the beauty of the architectonic houses in the town, and its landscapes.

Bellavista is deemed as an area of low tourist inflow. Then, it is necessary to work on its image and tourist promotion. It is situated in El Oro province, Ecuador, a rural Parish that belongs to the Canton of Santa Rosa, formed by riverine communes and the following sites: La Florida, Miraflores, San Jacinto, Laguna de Caña and San José (Ministerio del Ambiente, 2009).

A promotion of the tourism potential of Bellavista may be facilitated by means of different mass media resources, it is hereby recommended to make use of pictures that stand out the local landscapes (Echtner \& Prasad, 2003; Kim \& Richardson, 2003; Scherrer, 2014). Nevertheless, the purpose of the present research only deals with the influence of tourism in the target area, providing guidelines 
for future strategies to implement, aiming to protect the sociocultural integrity of the area.

\section{LITERATURE REVIEW}

For the elaboration of the present article, studies on the connection between hospitality and motivation were reviewed (Cimbaljević, 2015, Otting \& Zwaal, 2011), strategic planning research in hospitality and tourism were also considered (Phillips \& Moutinho, 2014; Ruhanen, Weiler, Moyle, \& McLennan, 2015), commune perceptions of tourism (Moyle et al., 2010; Routledge, 2006), sustainability indicators for different types of destinations, including those classified as vulnerable (Cornet, 2007), the tourism and its effects on the local economy (Song, Haiyan, Larry Dwyer \& ZhengCao, 2012), aspects of promotion and advertising (Wang et al., 2012; Witell \& Löfgren, 2013) and the sociocultural impact of tourism (Brunt \& Courtney, 1999; Dogan, 1989; Faulkner \& Tideswell, 1997; Korstanje, 2012).

The work developed by (Córdova, 2003) claims that the objective of rural tourism is directed to both tourists and individuals who permanently occupy the space in which tourism is developed. Local or host communes are as important in this system as the landscape and the tourist. In this sense, development actions should be framed within said parameters to improve the quality of life of rural populations. In this case, a study was carried out in the region of Colca Valley, Arequipa, Peru, which shows landscapes entirely cultural and patrimonial for tourism. On the other hand, there is an amazing fauna in the rocky mountains like the condor, bird symbol of the Andes, which allows its sightings to tourists.

The research carried out by (Garin, 2014) determines that rural tourism is an activity in process of consolidation as an engine for the development of peasant communes, a complement to their traditional productive work and the use of natural, gastronomic, historical, and landscape resources at their disposal. Taking into account these perspectives, the objective of this study is to analyze the role of public institutions, their relationships with local entrepreneurs, and characterize the peasants who make rural tourism, know their perception of local institutions and government, and be aware of the limitations and benefits available to perform their activity.

The article elaborated by (García, Cánoves, Salamaña, Valdovinos, \& Villarino, 1995), establishes as a research objective the analysis of the changing role of women in the economic activity of rural areas of Spain, particularly with a new rural tourism activity articulating a process divided into four preponderant phases: first, the theoretical framework of rural tourism is outlined, secondly the subject is streamlined in depth, the research methodology is applied in the third step and in the fourth, the results obtained are discussed. It is concluded thereby that women are highly enterprising for the sustainable development of rural communes, moreover in rural tourism.

\section{METHODOLOGY}

For the drafting of this document, a bibliographic review is made for the theoretical background. In addition, exploratory and statistical research are utilized in order to characterize the results shown in the field research. Said research was developed with a survey-type measurement instrument to synthesize the factors under study. The collected data allowed to establish the critical factors at a socio-cultural level related to the tourism development of a place. The information compiled in turn, may serve as a basis for the proposal of development for a model of sustainable tourism in the target area that minimizes the sociocultural impact (Noblecilla G., Ortíz B., Ruiz C., Encalada L., \& Ordoñez C., 2016).

For the present population, the parish of Bellavista was selected as a point of study, specifically the sites surrounding La Tembladera wetland, areas known as Riparian Communes. Table 1 shows the base referential population of the inhabitants of the riparian communes in the parish of Bellavista (Ministerio del Ambiente, 2009). For the year 2010, the population by area, according to province, Canton and parish of registration reflected a potential total of 2835 inhabitants (Instituto Nacional de Estadística y Censo, 2010). 
TABLE 1. Estimated population in riparian communes (\%).

\begin{tabular}{lccc}
\hline Location & \multicolumn{2}{c}{ Gender } & \multirow{2}{*}{ Total } \\
\cline { 2 - 3 } & Male & Female & \\
\hline La Florida & 10 & 9 & 19 \\
Miraflores & 4 & 5 & 9 \\
San Jacinto & 4 & 3 & 7 \\
Laguna de Caña & 16 & 14 & 30 \\
San José & 18 & 17 & 35 \\
Total & 51 & 49 & 100 \\
\hline
\end{tabular}

Source: Family surveys, Socio-economic component, La Tembladera Wetland Management Plan - 2009; IV Census of Population and V of Housing, November 2001, INEC.

Edition: The author

Factors were measured by using a Likert scale survey, which can provide a relevant framework to help estimate and analyze the factors of major and minor relevance in this research (Chou, Hsu, \& Chen, 2008; Faulkner \& Tideswell, 1997). Several analysis have been carried out on tourism in underdeveloped countries, reflecting a low balance of revenues generated by tourism activities (Brohman, 1996; Echtner \& Prasad, 2003; Korstanje, 2016). Hence, the need to generate strategies that boost tourist development; the expectation is not to affect the socio-cultural environment of the residents of the tourist attractions (Brunt \& Courtney, 1999; McKercher, Wang, \& Park, 2015).

The main source of information to determine the incidence of tourism in the socio-cultural development of the inhabitants of a place is based on themselves, which leads us to propose a survey to collect evidence of the socio-cultural impact (Ruhanen, Weiler, Moyle, \& McLennan, 2015). The survey elements include different estimation factors that reflect the reality of tourism from the perspective of residents and possible changes or socio-cultural adaptations, especially in those people who earn their income directly from tourists or activities developed during their visit (Jamal \& Getz, 1995; Jonas \& Reza, 2008).

One of the typical tourist services has to do with gastronomy, even in areas with low tourist affluence, although presenting a limited offer, limiting its commercial growth too (Jusoh, Shafiee, \& Jamaluddin, 2012). In the case of a small tourist affluent, it would not make sense to implement marketing strategies without previously working on the image and promotion of the tourist site (Kim \&
Richardson, 2003; Zhang, L'Espoir Decosta, \& McKercher, 2015). The best months for the tourism industry are January, March, June, July, August and December. The high season is considered in the months of June, July and August, due to the arrival of international visitors (Ministerio de Turismo, 2009).

In order to infer relevant aspects of the information, a survey model was used with a part of the population, estimated after calculating a representative sample. The questioned elements are shown in Table 2. For the weights, a Likert scale was considered for eleven of the twelve items included in the written survey, and an open question that later encompassed four types of results. The latter information is summarized in Table 3.

The research method is statistical and exploratory. Therefore, the data obtained will be systematically described (García-García, Reding-Bernal, \& López-Alvarenga, 2013; Kindström \& Kowalkowski, 2009), then, said data was tabulated with the help of IBM SPSS Statistics 23 trial software. The study takes on aspects of hospitality, community social environment and interaction between the commune residents and tourists in different seasons (Griffiths \& Sharpley, 2012; Jonas \& Reza, 2008).

For the calculation of the sample, it was decided to randomly select two of the sites in the study target area (three if the selected population is less than $50 \%$ of the total of 2835); then, the sites of San José and La Florida were selected, making up $54 \%$ of the estimated total population of the Santa Rosa Canton riparian communes (Table 1). 


\section{TABLE 2. Elements of the survey.}

\begin{tabular}{|c|c|}
\hline Item & Questioning \\
\hline 1 & Do you believe that tourism has in some way affected the development opportunities of the local community? \\
\hline 2 & Do you consider that your habitual family life is affected by tourism? \\
\hline 3 & Is the time spent with your family affected during peak tourist seasons? \\
\hline 4 & Do you consider that the majority of the residents that migrate to the city do it to find a job? \\
\hline 5 & Do you think that community life is affected in any way by tourism? \\
\hline 6 & Do you consider that there are resentments between the local community and the tourists? \\
\hline 7 & $\begin{array}{l}\text { Do you think that social exchange activities between tourists and the local community can lead to a change } \\
\text { in the attitude of the local community? }\end{array}$ \\
\hline 8 & Do you think that your lifestyle is temporarily altered during the tourism season? \\
\hline 9 & $\begin{array}{l}\text { Do you think that as a result of tourism, visitors are more interested in local development than the } \\
\text { local community? }\end{array}$ \\
\hline 10 & Do you consider that the local people change their beliefs to accommodate some of the tourists? \\
\hline 11 & Do you feel that your safety is affected in any way during the tourist season? \\
\hline 12 & Why are you living in this community? \\
\hline
\end{tabular}

Source: (Brunt \& Courtney, 1999).

Edited by: the author.

Therefore, the population to be studied $(\mathrm{N})$ is composed of 1531 inhabitants; In addition, a margin of error $(\varepsilon)$ of $5 \%$ was considered for the calculation, given the small population of the zone with a confidence level (z) of $95 \%$, using the following relation:

$$
n=\frac{p \times q \times z^{2}}{\varepsilon^{2}+\frac{p \times q \times z^{2}}{N}}
$$

Where $\mathrm{p}$ and $\mathrm{q}$ are the proportions of the population with both an expected and an unexpected characteristic respectively, taking the value of 0.5 for each case since there is no need for difference among the inhabitants of the sector, men and women of legal age are equally acceptable. Thus, the sample size (n) reaches 308 units of study, equivalent to a total of 77 families, considering that each family consists of four members on average (García-García et al., 2013). To reduce the estimation error, the sample was increased, rounding up to 80 surveys to be applied in the households of two sites randomly selected.
TABLE 3. Weights to table the surveys.

\begin{tabular}{lcc}
\hline Weighing & Likert scale & Open question \\
Totally disagree & 1 & - \\
Disagree & 2 & - \\
Neutral & 3 & - \\
Agree & 4 & - \\
Totally agree & 5 & - \\
Enjoy nature & - & 1 \\
Place of birth & - & 2 \\
Workplace & - & 3 \\
Like the community & - & 4 \\
environment & &
\end{tabular}

Source: (Brunt \& Courtney, 1999; Faulkner \& Tideswell, 1997). Edited by: The autor.

\section{RESULTS}

In the analysis of the collected data, to start, the reliability of the records was verified, by using a reliability analysis with Cronbach's alpha, which resulted in 0.992 (according to the test performed with the help of the IBM SPSS Statistics trial version), a result that indicates that the data are highly reliable (Table 4). After the tabulation, the main ele- 
ments that show a greater interaction with the rest of the elements are verified using a factorial analysis, which reflects a percentage of the variance higher than $90 \%$ over only one of the components (Table 5).

Table $\mathbf{N}^{\circ} 4$. Cronbach alpha value of the survey data.

\begin{tabular}{ccc} 
& \multicolumn{2}{c}{ Reliability statistics } \\
Cronbach Alfa & Cronbach alpha based on standardized elements & N of elements \\
, 992 &, 992 & 11 \\
\hline
\end{tabular}

Source: Analysis performed with IBM SPSS software.

Edited by: The author.

The element with the greatest incidence is the personal safety of the residents, who affirm that it is not affected by the flow of visitors during the local tourist seasons. This element is the one with the closest relation with the other elements analysed (from the point of view of the variability present in each set of values analysed bilaterally). However, the information repor- ted gives us different results which are detailed separately, contrasting their central tendencies, modal and median values. In the interactions the total variance by component is valued and the components are categorized. This usually proceeds after defining the commonalities; however, the presentation of these results is omitted.

TABLE 5. Factorial analysis of the elements in the survey.

\begin{tabular}{ccccccc}
\hline \multirow{2}{*}{ Component } & \multicolumn{5}{c}{ Initial autovalues } & \multicolumn{2}{c}{ Additions of extraction of squared charges } \\
\cline { 2 - 6 } & Total & \% of variance & \% accrued & Total & \% of variance & \% accrued \\
\hline 1 & 11,033 & 91,945 & 91,945 & 11,033 & 91,945 & 91,945 \\
2 &, 358 & 2,987 & 94,932 & & \\
3 &, 188 & 1,564 & 96,496 & & \\
4 &, 123 & 1,026 & 97,522 & & \\
5 &, 073 &, 605 & 98,127 & & \\
6 &, 066 &, 551 & 98,678 & & \\
7 &, 049 &, 407 & 99,085 & & \\
8 &, 038 &, 319 & 99,404 & & \\
9 &, 026 &, 221 & 99,625 & & \\
10 &, 021 &, 173 & 99,798 & & \\
11 &, 016 &, 137 & 99,936 & & \\
12 &, 008 &, 064 & 100,000 & & \\
\hline
\end{tabular}

Extraction method: analysis of main components. Source: Analysis performed with IBM SPSS software. Edited by: The author. 
TABLE 6. Main components of the survey.

\begin{tabular}{lc}
\hline \multicolumn{1}{c}{ Component matrix ${ }^{\text {a }}$} & Component/1 \\
\hline Do you believe that tourism has affected in some way the development opportunities of the &, 976 \\
local community? &, 977 \\
Do you consider that your family life is affected by tourism? &, 938 \\
Is the time spent with your family affected during peak tourist seasons? &, 913 \\
Do you consider that the majority of the residents that migrate to the city do it to find a job? &, 983 \\
Do you think that community life is affected in any way by tourism? &, 966 \\
Do you consider that there are resentments between the local community and the tourists? &, 937 \\
Do you think that social exchange activities between tourists and the local community can &, 975 \\
lead to a change in the attitude of the local community? &, 972 \\
Do you think that your lifestyle is temporarily altered during the tourism season? &, 974 \\
Do you think that as a result of tourism, visitors are more interested in local development &, 983 \\
than the local community? &, 908 \\
Do you consider that the local people change their beliefs to accommodate some of the tourists? \\
Do you feel that your safety is affected in any way during the tourist season? \\
Why are you living in this community?
\end{tabular}

Extraction method: main component analysis.

a. 1 extracted components.

Source: Analysis performed with IBM SPSS software.

Edited by: The author.

According to the results summarized in Table 7, it can be seen that tourism has not exerted a considerable impact on the opportunities of development for the local community; the residents of this community consider that their habitual family life is not affected by tourism in any way. Likewise, the time that the members of this community dedicate to their families is not affected during the high seasons of tourism. Most of the residents who migrate to the city do so to find employment. Besides, community life, or social coexistence with other residents, is not affected in any way by tourism. Finally, there is no evidence of any kind of resentment between the local community and the tourists. On this regard, residents are interested in the activities of social exchange between tourists and members of this community, although they are neutral on the idea of the need to generate a change in the attitude of this population.

It was also verified that the lifestyle of the target com- mune inhabitants undergoes a low impact during the tourist season, without perceiving relevant changes as a result of tourism, and specifically tourism potential, local development is of interest to both visitors and the local community. Their beliefs are rarely changed to accommodate tourists. Residents feel that their personal and familiar safety is not affected in any way during the tourist season. In general, the people who inhabit this sector in the sense that it is their place of origin, where they or their ancestors were born, and they have been given this place of residence as their legacy. Among the most influential factors at the level of the local population is related to the time that the residents dedicate to their families during the high seasons of tourism (June, July and August), which they consider that is not affected, according to $79 \%$ of respondents. Meanwhile 70\% consider that tourism does not alter their normal family life either. According to $69 \%$ the development opportunities are not affected by the tourist affluent in the analysed area. 
TABLE 7. Basic descriptive statistical elements.

\section{Questioning}

Do you believe that tourism has in some way affected the development opportunities of the local community?

Do you consider that your family life is affected by tourism?

Is the time spent with your family affected during peak tourist seasons?

Do you consider that the majority of the residents that migrate to the

city do it to find a job?

Do you think that community life is affected in any way by tourism?

Do you consider that there is resentment between the local

community and the tourists?

Do you think that meeting activities between tourists and the local community

can lead to a change in the attitude of the local community?

Do you think that your lifestyle is temporarily altered during the tourism season?

Do you think that as a result of tourism, visitors are more interested in local

development than the local community?

Do you consider that the local people change their beliefs to

accommodate some of the tourists?

Do you feel that your safety is affected in any way during the tourist season?

Why are you living in this community?

Source: (Brunt \& Courtney, 1999).

$\begin{array}{ccc}\text { Mode } & \text { Median } & \text { S.D. } \\ 2 & 2 & 1,370 \\ 1 & 2 & 1,280 \\ 1 & 2 & 1,196 \\ & & \\ 4 & 4 & 1,302 \\ 1 & 2 & 1,393 \\ & & \\ 1 & 2 & 1,137 \\ & & \\ 4 & 3 & 1,400 \\ 2 & 2 & 1,245 \\ 1 & 3 & 1,398 \\ 2 & 2 & 1,230 \\ 1 & 2 & 1,413 \\ 2 & 2 & 0,938\end{array}$

Edited by: The author.

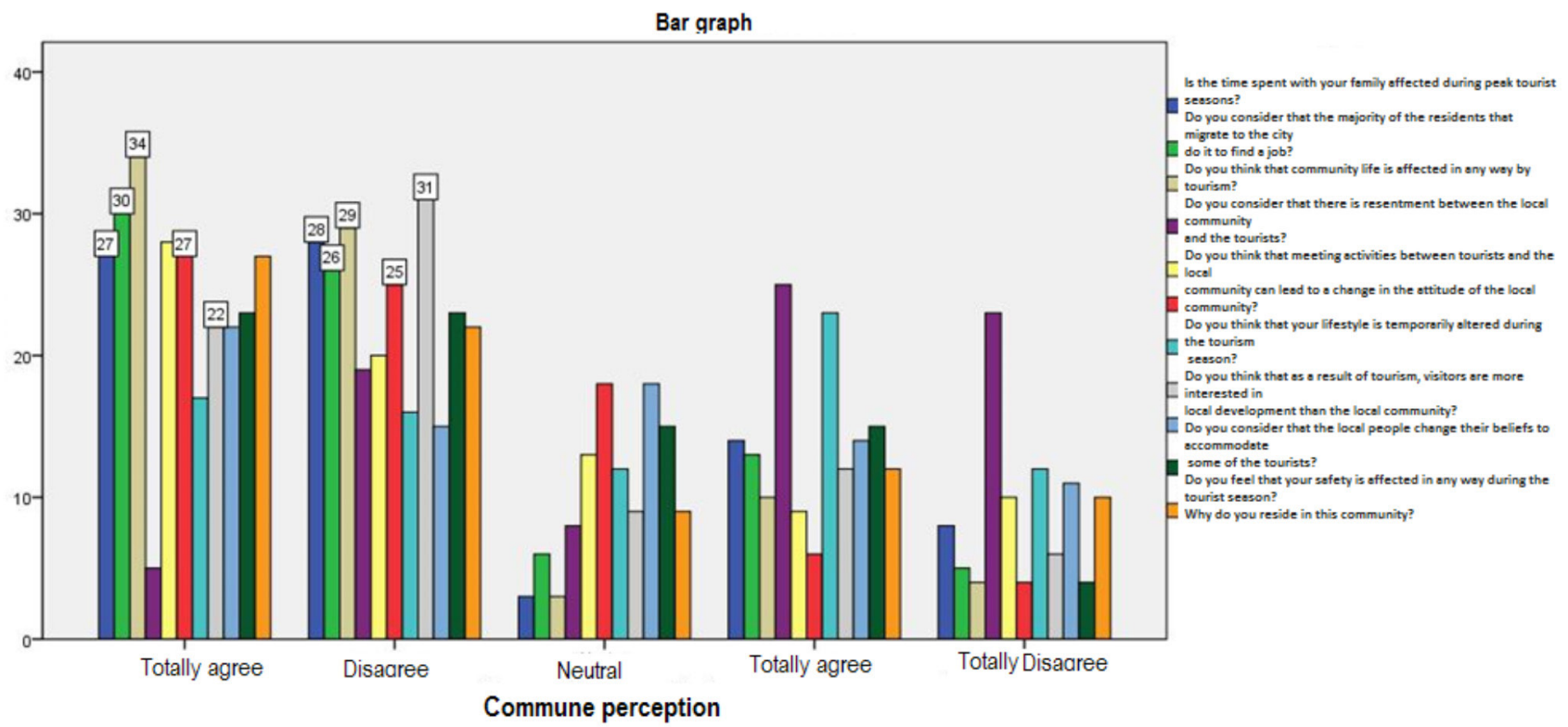

GRAPH 1. Bar graph on the commune perception of local tourism.

The last is also verified, according to Graph 1, that $66 \%$ of the respondents believe that their lifestyle does not suffer alterations derived from the tourist affluent. Another relevant factor is related to the resentment that might exist between the local community and the tourists; according to $65 \%$ this has not been evidenced. Finally, Graph 2 shows that $62.5 \%$ of the inhabitants of the sector have lived there from their birth or their ancestors' birth. 


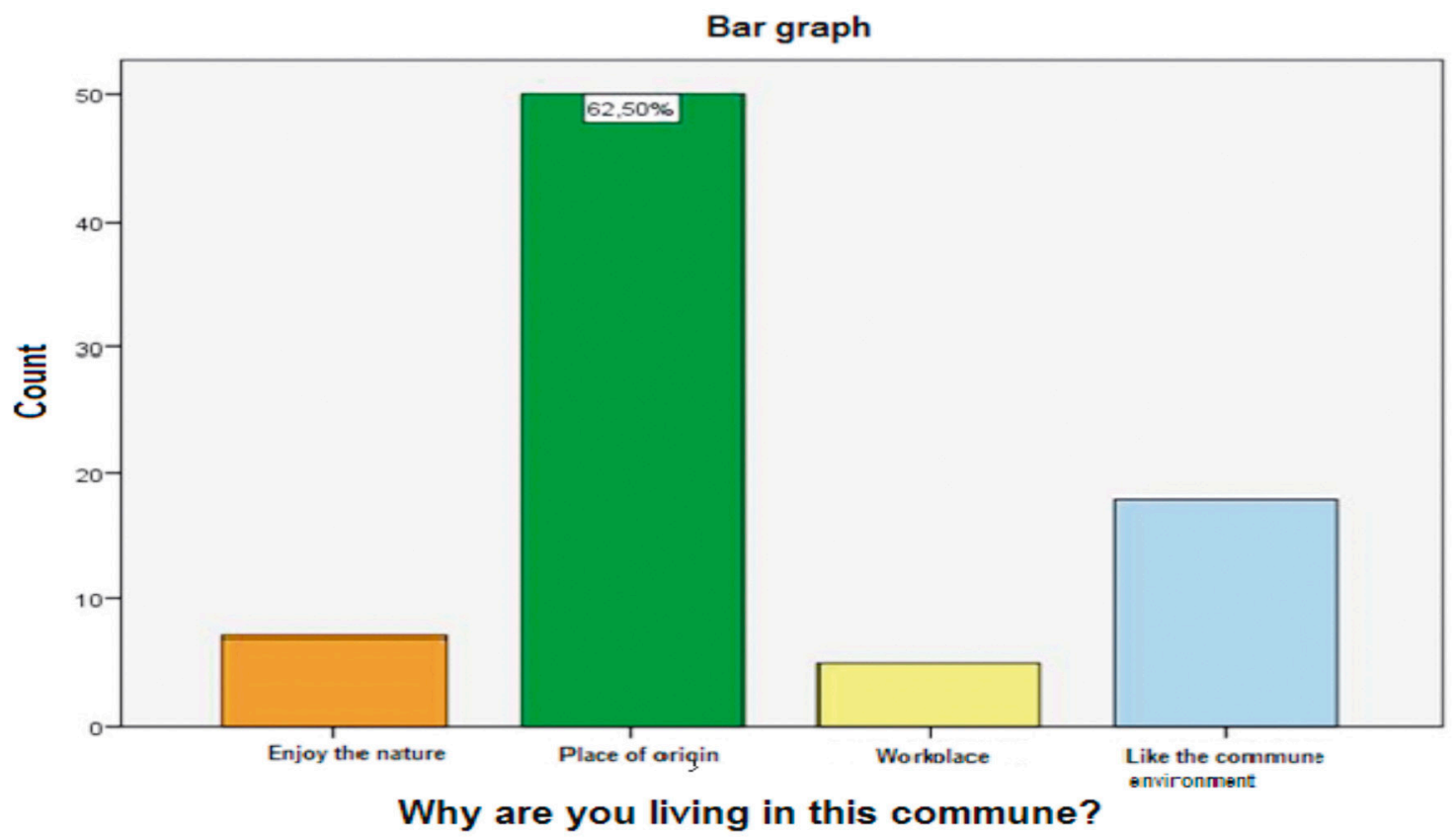

GRAPH 2. Bar graph on the reason of local residence.

\section{DISCUSSION}

In the present research the perception of the inhabitants of the Parish of Bellavista on the sociocultural impact derived from the tourist affluent in the area was examined, during high and low seasons of tourist activities. For this essay, documents dealing with issues about the socio-cultural impact of tourism development were analysed, as well as the interaction and influence between rural communities and tourism development. For the collection of information, a survey model was used containing the factors that were wanted to be visualized in order to determine the sociocultural influences of tourism perceived by the local community.

The main conclusions of this study reflect that tourism has not altered the time that residents dedicate to their families, their habitual family life, nor their lifestyle in the community. Development opportunities remain essentially intact given the low impact that tourism exerts on the sector, which is reflected in the absence of discrepancies, rivalries or resentment between residents and visitors. In addition, the population is mostly composed of people who inhabit the sector from their birth, or have spent their time from generation to generation.
Although there are studies that point to a typical change in the attitude of people when the tourist influx increases (Li, Chen, Li, \& Goh, 2016; Liu \& Var, 1986; Russell, 2003; Tucker, 2016), on the perception that residents in a place have about tourism development (Andereck, Valentine, Knopf, \& Vogt, 2005; Haralambopoulos \& Pizam, 1996; Liu, Sheldon, \& Var, 1987) and its sociocultural impact on the visited commune (Korstanje, 2012; Milman \& Pizam, 1988; Tosun, 2002), it is worth to highlight the positive attitude of the members of these communities, the facilities they provide to tourism and the local development evoked by it. However, a solid sustainable development proposal has not yet materialized, which can be complemented with a new study on this regard, analysing other variables of support (Nunkoo \& Gursoy, 2012; Stamenkovic, 2012; Torres-Delgado \& Palomeque, 2014).

Research works of this type will be a support to the different efforts and projects carried out in this sector, specifically around the protected ecological sector of the La Tembladera wetland (Ministerio del Ambiente, 2009), which includes socio-cultural studies, economic and tourism development, foreign trade, among others that seek 
to invigorate the regional resources. The implementation of a solid project of sustainable tourism for this area will promote the improvement of other fields, especially the commercial area, essential for the inhabitants of this community.

In the research carried out by Hildegardo Córdova (2003), there is a growing perception in the socio-cultural development in the mountainous areas of Arequipa where bird sightings are made, and also rural tourism of great relevance. In this case, it differs from the present research work since the Case study in Bellavista is a wetland called La Tembladera, whose strategic point according to the results obtained is that practically everything can be done, from adventure tourism, cultural, gastronomic and agricultural experiences, and which meeting points are highly touristic.

On the other hand, the work carried out by Alan Garín (2014), determines the perception of rural tourism in the local development of the commune members, which has a positive effect among the population of Villarica Chile, differing from the current research work in the sense that the background of this project is to analyse the tourist attractions offered by the wetland, using a better methodology than the one developed by Garín, as it was analysed statistically to support the proposed objective.

\section{CONCLUSIONS}

The community perception of tourism depends to a large extent on the proximity of the tourist to the residents. According to this research, each area will see tourism in a different way, because of the magnitude of the relationship or links that visitors might have with residents. For the commune members of San José and La Florida, administrative venue of the parish of Bellavista, the flow of tourism is really reduced, sometimes imperceptible, and the little time of tourist-commune member interaction is carried out in a harmonious way. Hence the minimal influence of tourism in this rural area of the canton Santa Rosa, which is already implementing several measures of community action to develop and enhance tourism.

The tourist potential, an imperative need for this community, which is supported by the good will of the residents to welcome visitors and improve the provision of services (in some cases) or simply by displaying hospitality. The positive community perception of tourism for the case under study stands out. This research would be complemented in the future, when the local community projects turn the site into a tourist destination sufficiently resorted to merit a new, deeper study that not only captures the perception about tourism, but also its impacts derived.

Residents, who are mostly native, may see their surroundings affected positively or negatively. That situation can be envisaged by promoting rural tourism with parallel measures of environmental conservation, especially when these areas surround La Tembladera wetland, a protected site that is the main attraction and source of tourism in these rural communities.

\section{REFERENCES}

Andereck, K. L., Valentine, K. M., Knopf, R. C., \& Vogt, C. A. (2005). Residents' perceptions of community tourism impacts. Annals of Tourism Research, 32(4), 1056 1076. http://doi.org/10.1016/j.annals.2005.03.001

Bramwell, B. (2015). Theoretical activity in sustainable tourism research. Annals of Tourism Research, 54, 204 218. http://doi.org/10.1016/j.annals.2015.07.005

Brohman, J. (1996). New directions in tourism for Third World development. Annals of Tourism Research, 23(1), 48-70. http://doi.org/10.1016/01607383(95)00043-7

Brunt, P., \& Courtney, P. (1999). Host perceptions of sociocultural impacts. Annals of Tourism Research, 26(3), 493-515. http://doi.org/10.1016/S01607383(99)00003-1

Chen, F. H., Hsu, T. S., \& Tzeng, G. H. (2011). A balanced scorecard approach to establish a performance evaluation and relationship model for hot spring hotels based on a hybrid MCDM model combining DEMATEL and ANP. International Journal of Hospitality Management, 30(4), 908-932. http://doi.org/10.1016/j. ijhm.2011.02.001

Chou, T.-Y., Hsu, C.-L., \& Chen, M.-C. (2008). A fuzzy multi-criteria decision model for international tourist hotels location selection. International Journal of Hospitality Management, 27(2), 293-301. http://doi.org/10.1016/j.ijhm.2007.07.029 
Cimbaljević, M. (2015). Social media marketing in tourism and hospitality. Annals of Tourism Research, 54, 236238. http://doi.org/10.1016/j.annals.2015.05.006

Cornet, C. (2015). Tourism development and resistance in China. Annals of Tourism Research, 52, 29-43. http:// doi.org/10.1016/j.annals.2015.02.002

Dogan, H. Z. (1989). Forms of adjustment. Annals of Tourism Research, 16(2), 216-236. http://doi. org/10.1016/0160-7383(89)90069-8

Dolnicar, S., Yanamandram, V., \& Cliff, K. (2012). The contribution of vacations to quality of life. Annals of Tourism Research, 39(1), 59-83. http://doi.org/10.1016/j.annals.2011.04.015

Echtner, C. M., \& Prasad, P. (2003). The context of third world tourism marketing. Annals of Tourism Research, 30(3), 660-682. http://doi.org/10.1016/S01607383(03)00045-8

Faulkner, B., \& Tideswell, C. (1997). A framework for monitoring community impacts of tourism. Journal of Sustainable Tourism, 5(1), 3-28. http://doi. org/10.1080/09669589708667273

García-García, J. A., Reding-Bernal, A., \& López-Alvarenga, J. C. (2013). Cálculo del tamaño de la muestra en investigación en educación médica. Investigación En Educación Médica, 2(8), 217-224. http://doi. org/10.1016/S2007-5057(13)72715-7

Griffiths, I., \& Sharpley, R. (2012). Influences of nationalism on tourist-host relationships. Annals of Tourism Research, 39(4), 2051-2072. http://doi.org/10.1016/j.annals.2012.07.002

Haralambopoulos, N., \& Pizam, A. (1996). Perceived impacts of tourism. Annals of Tourism Research, 23(3), 503-526. http://doi.org/10.1016/01607383(95)00075-5

Jamal, T. B., \& Getz, D. (1995). Collaboration theory and community tourism planning. Annals of Tourism Research, 22(1), 186-204. http://doi. org/10.1016/0160-7383(94)00067-3

Jensen, M. T. (2016). Hypersensitive tourists: The dark sides of the sensuous. Annals of Tourism Research, 57, 239-242. http://doi.org/10.1016/j.annals.2016.01.002
Jonas, S. H., \& Reza, B. (2008). Hospitality studies and hospitality management: A symbiotic relationship. International Journal of Hospitality Management, 101, 8357-8361.

Jusoh, Z., Shafiee, N. H., \& Jamaluddin, A. (2012). Factors Influencing Tourist Food Consumption. International Journal of Hospitality Management, 1-27.

Kim, H., \& Richardson, S. L. (2003). Motion picture impacts on destination images. Annals of Tourism Research, 30(1), 216-237. http://doi.org/10.1016/ S0160-7383(02)00062-2

Kindström, D., \& Kowalkowski, C. (2009). Development of industrial service offerings: a process framework. Journal of Service Management, 20(2), 156-172. http://doi.org/10.1108/09564230910952753

Korstanje, M. E. (2012). Turismo y Cambio Sociocultural: Una Perspectiva Conceptual. Annals of Tourism Research, 39(2), 1264-1266. http://doi.org/10.1016/j. annals.2012.01.009

Korstanje, M. E. (2016). Sun \& sea tourism: Fantasy and finance of the all-inclusive industry. Annals of Tourism Research. http://doi.org/10.1016/j.annals.2016.02.012

Li, H., Chen, J. L., Li, G., \& Goh, C. (2016). Tourism and regional income inequality: Evidence from China. Annals of Tourism Research, 58, 81-99. http://doi.org/10.1016/j.annals.2016.02.001

Liu, J. C., Sheldon, P. J., \& Var, T. (1987). Resident perception of the environmental impacts of tourism. Annals of Tourism Research, 14(1), 17-37. http://doi. org/10.1016/0160-7383(87)90045-4

Liu, J. C., \& Var, T. (1986). Resident attitudes toward tourism impacts in Hawaii. Annals of Tourism Research, 13(2), 193-214. http://doi.org/10.1016/0160-7383(86)90037-X

McKercher, B., Wang, D., \& Park, E. (2015). Social impacts as a function of place change. Annals of Tourism Research, 50, 52-66. http://doi.org/10.1016/j.annals.2014.11.002

Milman, A., \& Pizam, A. (1988). Social impacts of tourism on central florida. Annals of Tourism Research, 15(2), 191-204. http://doi.org/10.1016/01607383(88)90082-5 
Moyle, B., Croy, W. G., \& Weiler, B. (2010). Community Perceptions of Tourism: Bruny and Magnetic Islands, Australia. Asia Pacific Journal of Tourism Research, 15(3), 353-366. http://doi.org/10.1080/10941665.2 010.503625

Noblecilla G., M., Ortíz B., L., Ruiz C., J., Encalada L., I., \& Ordoñez C., O. (2016). Análisis del potencial turístico de las comunidades rurales. Caso de estudio: Comunidad Muyuyacu , El Oro-Ecuador. RIAT, 12, 48-59. Retrieved from http://riat.utalca.cl/index.php/test/ article/view/322

Nunkoo, R., \& Gursoy, D. (2012). Residents' support for tourism. Annals of Tourism Research, 39(1), 243-268. http://doi.org/10.1016/j.annals.2011.05.006

Otting, H., \& Zwaal, W. (2011). Degree of motivation of international hospitality students in their work place. Journal of Hospitality Leisure Sport \& Tourism Education, 10(1), 4-12. http://doi.org/10.3794/johlste.101.240

Phillips, P., \& Moutinho, L. (2014). Critical review of strategic planning research in hospitality and tourism. Annals of Tourism Research, 48, 96-120. http://doi. org/10.1016/j.annals.2014.05.013

Routledge, P. (2006). Sustainable Wine Tourism: The Host Community Perspective. Journal of Sustainable Tourism, 14(5), 425-448. http://doi.org/10.2167/ jost587.0

Ruhanen, L., Weiler, B., Moyle, B. D., \& McLennan, C. J. (2015). Trends and patterns in sustainable tourism research: a 25-year bibliometric analysis Trends and Patterns in Sustainable Tourism Research: A 25- Year Bibliometric Analysis. Journal of Sustainable Tourism, 23(4), 517-535. http://doi.org/10.1080/09669582.2 014.978790

Russell, R. V. (2003). Tourists and refugees. Annals of Tourism Research, 30(4), 833-846. http://doi. org/10.1016/S0160-7383(03)00062-8

Sancho, A., Garcia, G., \& Rozo, E. (2007). Comparativa de Indicadores de Sostenibilidadpara Destinos Desarrolla- dos, en Desarrollo y con Poblacion Vulnerable. Annals of Tourism Resarch, 9, 15-77.

Scherrer, P. (2014). Book review. Annals of Tourism Research, 44, 294-296. http://doi.org/10.1016/j.annals.2013.08.006

Song, Haiyan, Larry Dwyer, G. L., \& ZhengCao. (2012). Tourism Economics Research: a Review and Assessment. Annals of Tourism Research, 39(3), 1653-1682. Retrieved from http:// ac.els-cdn.com/s0160738312000795/1 s2.0-S0160738312000795-main.pdf? ti$d=67 a 563$ e $4-c 8 d 4-11$ e 3 - bee $1-00000 a a b-$ Of02\&acdnat=1398030214_b57a4f3d9703ed2daf5a30d5da93eb92

Stamenkovic, P. D. (2012). Tourism: Characteristics and Development Perspectives. Annals of Tourism Research, 39(3), 1748-1749. http://doi.org/10.1016/j. annals.2012.05.016

Torres-Delgado, A., \& Palomeque, F. L. (2014). Measuring sustainable tourism at the municipal level. Annals of Tourism Research, 49, 122-137. http://doi. org/10.1016/j.annals.2014.09.003

Tosun, C. (2002). Host perceptions of impacts. Annals of Tourism Research, 29(1), 231-253. http://doi. org/10.1016/S0160-7383(01)00039-1

Tucker, H. (2016). Empathy and tourism: Limits and possibilities. Annals of Tourism Research, 57, 31-43. http:// doi.org/10.1016/j.annals.2015.12.001

Wang, C.-H., Chen, K.-Y., \& Chen, S.-C. (2012). Total quality management, market orientation and hotel performance: The moderating effects of external environmental factors. International Journal of Hospitality Management, 31(1), 119-129. http://doi.org/10.1016/j.ijhm.2011.03.013

Witell, L., \& Löfgren, M. (2013). From service for free to service for fee: business model innovation in manufacturing firms. Journal of Service Management, 24(5), 520-533. http://doi.org/10.1108/JOSM-04-20130103 
Zhang, C. X., L’Espoir Decosta, P., \& McKercher, B. (2015). Politics and tourism promotion: Hong Kong's myth making. Annals of Tourism Research, 54, 156171. http://doi.org/10.1016/j.annals.2015.07.003

Instituto Nacional de Estadística y Censo. (Noviembre de 2010). INEC. Obtenido de www.inec.gob. ec: http://www.inec.gob.ec/cpv/index.php?option=com_content\&view=article\&id=232\&Itemi$\mathrm{d}=128$ \&lang=es

Ministerio de Turismo. (Agosto de 2009). Plan Integral de Marketing Tutístico de Ecuador PIMTE 2014. Obtenido de www.turismo.gob.ec: http://www.turismo.gob. ec/wp-content/uploads/downloads/2013/02/PIMTE_2014.pdf

Ministerio del Ambiente. (Noviembre de 2009). Plan de manejo participativo del Humedal La Tembladera, El Oro - Santa Rosa. Obtenido de simce.ambiente.gob.ec: http://simce.ambiente.gob.ec/sites/default/files/documentos/belen/Plan\%20de\%20Manejo\%20La\%20 Tembladera.pdf 